Research

Open Access

\title{
Risk stratification of early admission to the intensive care unit of patients with no major criteria of severe community-acquired pneumonia: development of an international prediction rule
}

\author{
Bertrand Renaud1, José Labarère², Eva Coma ${ }^{3}$, Aline Santin ${ }^{1}$, Jan Hayon4, Mercé Gurgui ${ }^{5}$, \\ Nicolas Camus ${ }^{1,6}$, Eric Roupie ${ }^{7,8}$, François Hémery9 ${ }^{9}$, Jérôme Hervé1, Mirna Salloum¹, \\ Michael J Fine 10,11 and Christian Brun-Buisson6,12
}

\begin{abstract}
1Department of Emergency Medicine, AP-HP, Groupe Hospitalier Henri Mondor-Albert Chenevier, Créteil, F-94010, France 2Unité d'évaluation médicale, Centre Hospitalier Universitaire de Grenoble, Grenoble, F-38043, France

${ }^{3}$ Servei d'Atenció Continuada USAC, Institut Català d'Oncologia, Hospital Duran i Reynals, 08907 L'Hospitalet de Llobregat, Barcelona, Spain ${ }^{4}$ Department of Intensive Care Medicine, Centre Hospitalier Intercommunal de Poissy Saint-Germain, Saint-Germain-en-Laye, F-78100, France ${ }^{5}$ Department of Emergency Medicine, Hospital de la Santa Creu I Sant Pau, Barcelona, Spain

6Université Paris 12, Faculté de Médecine, Créteil, F-94000, France

7Department of Emergency Medicine, CHU de Caen, Hôpital Côte de Nacre, F-14033, Caen, France

8 Université de Caen-Basse Normandie, Faculté de médecine, F-14032, Caen, France

9Département d'Informatique Hospitalier (PMSI et Recherche Clinique), AP-HP, Groupe Hospitalier Henri Mondor-Albert Chenevier, Créteil, F94010 , France

${ }^{10}$ Center for Health Equity Research and Promotion, VA Pittsburgh Healthcare System, 7180 Highland Drive (151C-H), Pittsburgh, PA 15206-1206, USA

11Division of General Internal Medicine, Department of Medicine, University of Pittsburgh, UPMC Montefiore Hospital, Suite W933, 200 Lothrop

Street, Pittsburgh, PA 15213, USA

${ }_{12}$ AP-HP, Groupe hospitalier Henri Mondor-Albert Chenevier, Réanimation Médicale, Créteil, F-94010, France
\end{abstract}

Corresponding author: Bertrand Renaud, bertrand.renaud@hmn.aphp.fr

Received: 4 Jan 2009 Revisions requested: 18 Feb 2009 Revisions received: 18 Mar 2009 Accepted: 9 Apr 2009 Published: 9 Apr 2009

Critical Care 2009, 13:R54 (doi:10.1186/cc7781)

This article is online at: http://ccforum.com/content/13/2/R54

(c) 2009 Renaud et al.; licensee BioMed Central Ltd.

This is an open access article distributed under the terms of the Creative Commons Attribution License (http://creativecommons.org/licenses/by/2.0), which permits unrestricted use, distribution, and reproduction in any medium, provided the original work is properly cited.

\begin{abstract}
Introduction To identify risk factors for early $(<$ three days) intensive care unit (ICU) admission of patients hospitalised with community-acquired pneumonia (CAP) and not requiring immediate ICU admission, and to stratify the risk of ICU admission on days 1 to 3 .

Methods Using the original data from four North American and European prospective multicentre cohort studies of patients with CAP, we derived and validated a prediction rule for ICU admission on days 1 to 3 of emergency department (ED) presentation, for patients presenting with no obvious reason for immediate ICU admission (not requiring immediate respiratory or circulatory support).
\end{abstract}

Results A total of 6560 patients were included (4593 and 1967 in the derivation and validation cohort, respectively), $303(4.6 \%)$ of whom were admitted to an ICU on days 1 to 3 . The Risk of Early Admission to ICU index (REA-ICU index) comprised 11 criteria independently associated with ICU admission: male gender, age younger than 80 years, comorbid conditions, respiratory rate of 30 breaths/minute or higher, heart rate of 125 beats/minute or higher, multilobar infiltrate or pleural effusion, white blood cell count less than 3 or $20 \mathrm{G} / \mathrm{L}$ or above, hypoxaemia (oxygen saturation $<90 \%$ or arterial partial pressure of oxygen $\left(\mathrm{PaO}_{2}\right)<60 \mathrm{mmHg}$ ), blood urea nitrogen of $11 \mathrm{mmol} / \mathrm{L}$ or higher, $\mathrm{pH}$ less than 7.35 and sodium less than $130 \mathrm{mEq} / \mathrm{L}$. The REA-ICU index stratified patients into four risk classes with a risk of ICU admission on days 1 to 3 ranging from 0.7 to $31 \%$. The area under the curve was $0.81(95 \%$ confidence interval $(\mathrm{Cl})=0.78$ to 0.83 ) in the overall population.

Conclusions The REA-ICU index accurately stratifies the risk of ICU admission on days 1 to 3 for patients presenting to the ED with CAP and no obvious indication for immediate ICU admission and therefore may assist orientation decisions.

ATS: American Thoracic Society; CAP: community-acquired pneumonia; Cl: confidence interval; ED: emergency department; EDCAP: Emergency Department Community-Acquired Pneumonia; ICU: intensive care unit; IRVS: intensive respiratory or vasopressor support; OR: odds ratio; PORT: Patient Outcomes Research Team; PSI: Pneumonia Severity Index; REA-ICU: risk of early admission to ICU; ROC: receiver operating characteristics; SCAP: severe community-acquired pneumonia. 


\section{Introduction}

Approximately $10 \%$ of patients hospitalised for communityacquired pneumonia (CAP) are admitted to an intensive care unit (ICU), and these patients account for about $10 \%$ of all medical admissions to ICUs [1,2]. Although some patients with CAP have an obvious reason for ICU admission on the day of presentation to the emergency department (ED), a substantial proportion of others will develop organ failure within a few days [3]. Transfer to the ICU for delayed respiratory failure or delayed onset of septic shock is associated with increased mortality [4]. Hence, a major challenge in the management of CAP is to identify patients at risk for rapidly developing adverse medical outcomes among those presenting to the ED with no obvious reason for immediate ICU admission.

Since the publication of the American Thoracic Society (ATS) guidelines in 1993, several prediction rules have been derived to identify ED patients with severe CAP, defined by adverse outcomes (including ICU admission, shock requiring vasopressors, acute respiratory failure requiring mechanical ventilation or death). Most of these prediction rules were derived in populations including patients presenting with an obvious reason for immediate ICU admission. However, a prediction rule is essentially relevant to help management decisions for patients not requiring immediate respiratory or circulatory support at presentation to the ED [5]. Additionally, previous rules were designed to predict endpoints occurring within 30 days of ED presentation, which may be an excessively remote perspective, when considering both the viewpoint of the ED and ICU physicians' orientation decisions, and the potential relatedness of a late ICU transfer to physiological alterations caused by pneumonia itself.

Therefore, our goals were to identify risk factors for ICU admission within three days of hospital stay for patients initially presenting without respiratory failure or shock, and to derive and validate a prediction rule to stratify the risk of ICU admission on days 1 to 3 .

\section{Materials and methods Study design}

This study was based on data obtained from four prospective, multicentre studies in adults with pneumonia. Two were from North America, the Pneumonia Patient Outcomes Research Team (PORT) cohort study and the Emergency Department Community-Acquired Pneumonia (EDCAP) trial, and the two other cohorts were from Europe (Pneumocom-1 and Pneumocom-2). The methods used for the Pneumonia PORT, EDCAP and Pneumocom studies have been reported previously [6-9]. With the exception of the EDCAP cluster randomised trial, all studies were observational. The study protocols were approved by the institutional review boards of the participating institutions. We received permission to use the data from the four original multicentre studies and the need for informed consent for the specific purpose of this study was waived.

\section{Patients}

All studies enrolled consenting adults with pneumonia. Nursing home residents with health care-associated pneumonia were not eligible for the current analysis [10]. Additional exclusion criteria (discharge within 7 to 10 days of presentation, positive HIV antibody titre, immunosuppression, history of cystic fibrosis, ventilation via a tracheostomy or chronic use of mechanical ventilation) varied across the four original studies (Additional data file 1). Patients presenting with acute respiratory failure requiring mechanical ventilation (invasive or noninvasive mechanical ventilation) or shock (systolic arterial pressure below $90 \mathrm{mmHg}$ and requiring vasopressors) who were transferred to the ICU on the same day of ED presentation were considered to have an obvious indication for immediate ICU admission [11] and were excluded from the present analysis. For the purposes of this study, $70 \%$ of the patients were randomly assigned to a derivation cohort and 30\% to an internal validation cohort.

\section{Baseline data collection}

All four studies used physician interviews and standardised reviews of medical records to collect baseline demographic variables, comorbid illnesses, physical examination findings, laboratory test results and radiographic findings. According to previously published algorithms, prediction rules were derived from each patient's baseline data $[6,12,13]$. In accordance with methods used in these previous studies, missing variables were assumed to be normal $[14,15]$.

\section{Outcome measures}

The primary outcome measure was the occurrence of ICU admission on days 1 to 3 of ED presentation (Figure 1). The secondary outcome was 28-day all-cause mortality.

\section{Statistical analyses}

Baseline and follow-up characteristics were reported as mean and standard deviation or median and interquartile range for continuous variables, and as percentages for discrete variables. We compared patient baseline characteristics according to ICU admission on days 1 to 3 , using the two-tailed $t$ tests or Wilcoxon tests for continuous variables, and chi-squared tests or the Fisher's exact test for discrete variables.

We first developed a parsimonious logistic regression model by removing variables from the full main effects model using a backward approach with a cut-off value of $P=0.10$. The variables introduced in the model included demographic characteristics, comorbid conditions and physical, radiographic and laboratory findings. Subsequently, we transformed the regression coefficients of the variables in the final model to an integer value for each variable according to its contribution to the risk estimation. Finally, we derived a four risk class prediction rule for predicting ICU admission on days 1 to 3 , and estimated the area under the receiver operating characteristics (ROC) curve for predicting ICU admission on days 1 to 3 . We also esti- 


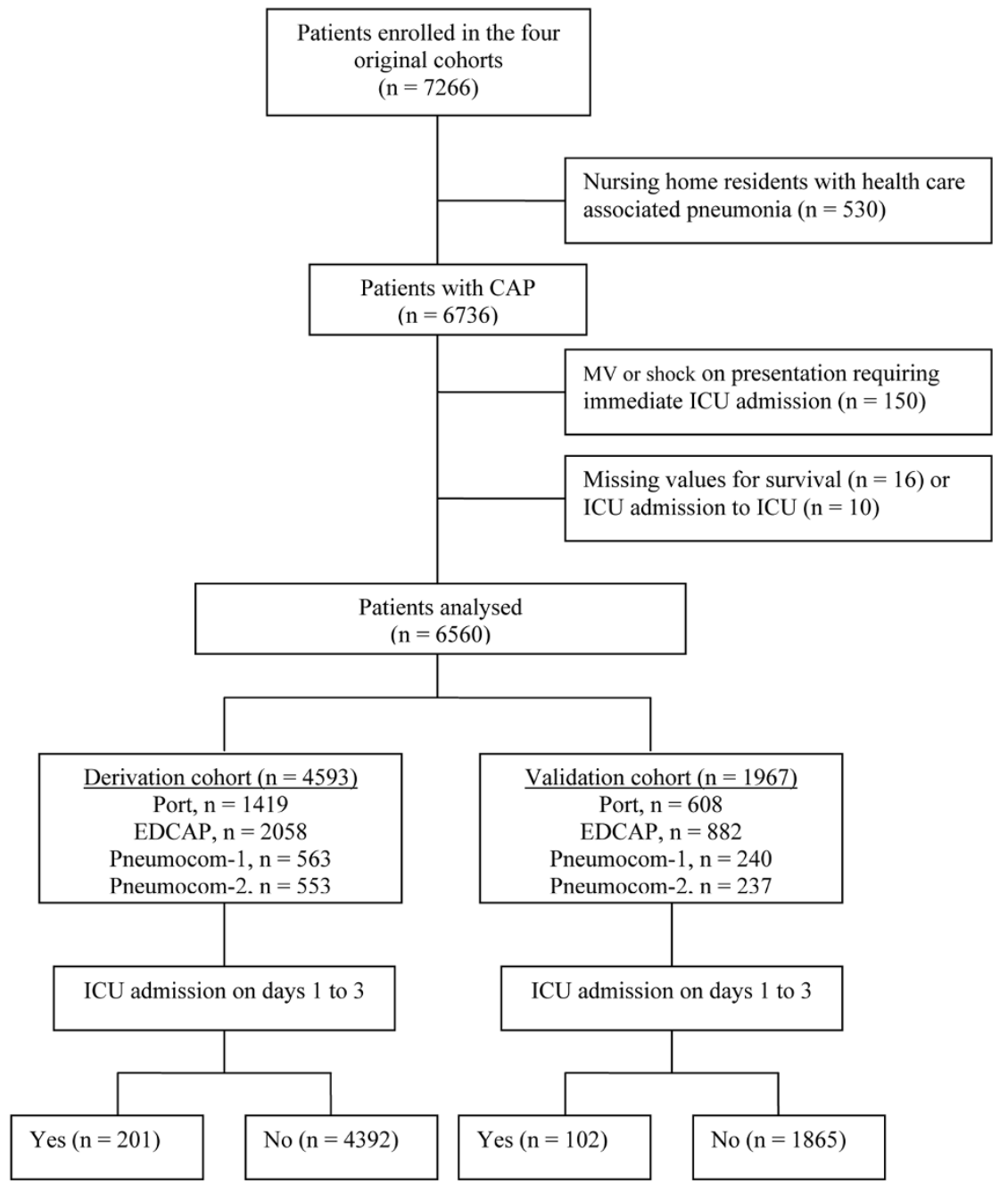

Patient enrolment. $\mathrm{CAP}=$ community-acquired pneumonia; EDCAP $=$ Emergency Department Community-Acquired Pneumonia; $I C U=$ intensive care unit; $\mathrm{MV}=$ mechanical ventilation.

mated the area under the ROC curve of our score within each original cohort. All analyses were performed using Stata version 8.0 (Stata Corporation, College Station, TX, USA).

\section{Results}

\section{Patient characteristics}

Overall, 6560 patients were retained in our analysis, including 4593 (70\%) in the derivation and 1967 (30\%) in the validation cohort (Figure 1). The characteristics of the two cohorts are compared in Tables 1 and 2.

\section{Outcomes measures}

During the 28-day follow-up, 378 patients were admitted to an ICU $(5.6 \%$ and $6.0 \%$, respectively in the derivation and validation cohorts; Table 2). More than $80 \%$ of ICU admissions occurred within three days of ED presentation. Conversely, nearly $80 \%$ of the 262 deaths occurred after three days, whereas about $20 \%$ (53) of the deaths occurred within three days of presentation.

\section{Factors associated with ICU admission on days 1 to 3} Baseline characteristics associated with ICU admission on days 1 to 3

Patients admitted to the ICU on days 1 to 3 were more likely to be elderly men with comorbidities, and to have more vital sign abnormalities (altered mental status, tachypnoea and hypotension), radiographic or laboratory abnormalities (hypoxaemia, hyponatraemia, acidosis, high blood urea nitrogen level, and pleural effusion or multilobar infiltrates; Tables 3 and 4).

\section{Independent risk factors}

In multivariable analysis, we identified 11 independent predictors of ICU admission on days 1 to 3 , including male gender, age under 80 years and at least one comorbid condition; all 
Table 1

Patient demographic characteristics, comorbid conditions and baseline physical examination findings

\begin{tabular}{|c|c|c|c|}
\hline Characteristics & $\begin{array}{l}\text { Derivation sample } \\
\qquad(n=4593)\end{array}$ & $\begin{array}{l}\text { Validation sample } \\
\qquad(\mathrm{n}=1967)\end{array}$ & $P$ value \\
\hline \multicolumn{4}{|l|}{ Demographic factors } \\
\hline Male gender, $\mathrm{n}(\%)$ & $2428(52.9)$ & $1040(52.9)$ & 0.99 \\
\hline Age, mean (SD), years & $60(20)$ & $60(20)$ & 0.48 \\
\hline \multicolumn{4}{|l|}{ Comorbid conditions, n (\%) } \\
\hline Neoplastic disease & $229(5.0)$ & $120(6.1)$ & 0.06 \\
\hline Liver disease & $71(1.5)$ & $30(1.5)$ & 0.95 \\
\hline Congestive heart failure & $542(11.8)$ & $235(11.9)$ & 0.87 \\
\hline Renal disease & $243(5.3)$ & $112(5.7)$ & 0.51 \\
\hline Coronary artery disease & $792(17.2)$ & $318(16.2)$ & 0.29 \\
\hline Chronic pulmonary disease & $1153(25.1)$ & $474(24.1)$ & 0.39 \\
\hline Diabetes mellitus & $672(14.6)$ & $284(14.4)$ & 0.84 \\
\hline \multicolumn{4}{|l|}{ Physical examination findings } \\
\hline Altered mental status, $\mathrm{n}(\%)$ & $275(6.0)$ & $120(6.1)$ & 0.96 \\
\hline Respiratory rate, median (IQR), per minute & 22 (20 to 26$)$ & 22 (20 to 26$)$ & 0.72 \\
\hline Pulse, median (IQR), per minute & 97 (84 to 112$)$ & 97 (84 to 110$)$ & 0.28 \\
\hline Systolic BP, median (IQR), mmHg & 132 (118 to 150$)$ & 131 (118 to 150$)$ & 0.67 \\
\hline Temperature, median (IQR), ${ }^{\circ} \mathrm{C}$ & 37.7 (36.8 to 38.5$)$ & 37.6 (36.8 to 38.5$)$ & 0.07 \\
\hline Oxygen saturation, median (IQR), \% & 94 (90 to 96$)$ & 94 (91 to 97$)$ & 0.07 \\
\hline
\end{tabular}

Missing values were assumed to be normal for respiratory rate $(n=819 ; 12 \%)$, pulse $(n=356,5 \%)$, systolic $(n=314,5 \%)$, temperature $(n=$ $323,5 \%)$ and comorbid conditions $(<2 \%)$. $\mathrm{BP}=$ blood pressure; $\mathrm{ICU}=$ intensive care unit; IQR $=$ interquartile range.

other independent risk factors were physical or laboratory findings (Table 5).

Risk of early admission to the ICU

The risk of early admission to the ICU (REA-ICU) score ranged from 0 to 17 and was stratified into four risk classes (REA-ICU index; Table 6). In the derivation cohort the rate of ICU admission on days 1 to 3 ranged from $1.1 \%$ for risk class I to $27.1 \%$ for risk class IV and 28-day mortality ranged from 1.2 to $15.1 \%$. Similar rates were observed in the validation cohort. In risk class I, five patients (not admitted to ICU) died within three days of ED presentation. The risk class I patients accounted for 2510 of 4593 (54.6\%) and 1099 of 1967 (55.9\%) patients, respectively, in the derivation and validation cohorts, with 27 out of $2510(1.1 \%)$ and 14 out of $1099(1.3 \%)$ of these patients admitted to the ICU, respectively. Among these 41 patients, 10 were classified as high-risk using the Pneumonia Severity Index (PSI) and none subsequently died.

The area under the ROC curves for the REA-ICU score was 0.80 (95\% confidence interval $(\mathrm{Cl})=0.77$ to 0.83$)$ and 0.80 $(95 \% \mathrm{Cl}=0.76$ to 0.84$)$ in the derivation and validation cohorts, respectively.
The risk of admission to the ICU on days 1 to 3 increased significantly from risk class I to risk class IV within each of the four original cohorts ( $P<0.001$ for each cohort). The area under the ROC curve of the score for predicting admission to an ICU on days 1 to 3 ranged from $0.76(95 \% \mathrm{Cl}=0.72$ to 0.90$)$ in the EDCAP cohort to $0.82(95 \% \mathrm{Cl}=0.85$ to 0.90$)$ in the Pneumocom-2 cohort.

The REA-ICU score yielded a higher area under the ROC curve than the $\mathrm{PSI}(0.75,95 \% \mathrm{Cl}=0.73$ to 0.78$)$, CURB-65 $(0.69,95 \% \mathrm{Cl}=0.66$ to 0.72$)$ and Espana Severe CAP (SCAP) $(0.74,95 \% \mathrm{Cl}=0.71$ to 0.76$)$ for predicting ICU admission on days 1 to 3 for patients not requiring immediate circulatory or ventilatory support $(P<0.001$ for all pairwise comparisons involving the REA-ICU score).

\section{Discussion}

In this study, we identified 11 baseline characteristics that were independently associated with ICU admission on days 1 to 3 in a broad range of patients presenting with CAP and no obvious reason for immediate ICU admission (i.e. not requiring immediate respiratory or circulatory support). These characteristics included male gender, age younger than 80 years, 
Table 2

\begin{tabular}{|c|c|c|c|}
\hline Characteristics & $\begin{array}{l}\text { Derivation sample } \\
\qquad(n=4593)\end{array}$ & $\begin{array}{l}\text { Validation sample } \\
\qquad(n=1967)\end{array}$ & $P$ value \\
\hline \multicolumn{4}{|l|}{ Laboratory and $\mathrm{x}$-ray findings } \\
\hline Arterial $\mathrm{pH}$, median (IOR) & 7.45 (7.41 to 7.47$)$ & 7.44 (7.41 to 7.47$)$ & 0.59 \\
\hline Arterial partial pressure of oxygen, median (IQR), $\mathrm{mmHg}$ & 63 (55 to 74$)$ & 64 (55 to 73$)$ & 0.62 \\
\hline BUN, median (IOR), mEq/L & $6(4$ to 9$)$ & $6(4$ to 9$)$ & 0.81 \\
\hline Sodium, median (IQR), mEq/L & 137 (134 to 139$)$ & 137 (134 to 139$)$ & 0.63 \\
\hline Glucose, median (IQR), \% & $7(6$ to 9$)$ & 7 (6 to 9$)$ & 0.97 \\
\hline Multilobar infiltrates & 39 (35 to 42$)$ & 39 (36 to 42$)$ & 0.48 \\
\hline WBC, median (IQR), G/L & 11.7 (8.5 to 15.8$)$ & $11.2(8.1$ to 15.3$)$ & 0.04 \\
\hline Multilobar infiltrates, $\mathrm{n}(\%)$ & & & 0.80 \\
\hline Pleural effusion, n (\%) & $503(10.9)$ & $206(10.5)$ & 0.57 \\
\hline Pneumonia Severity Index, n (\%) & & & 0.80 \\
\hline Class I & $1259(27.4)$ & $538(27.3)$ & \\
\hline Class II & $1075(23.4)$ & $479(24.3)$ & \\
\hline Class III & $877(19.1)$ & $372(18.9)$ & \\
\hline Class IV & $1104(24.0)$ & $451(22.9)$ & \\
\hline Class V & $278(6.0)$ & $127(6.5)$ & \\
\hline \multicolumn{4}{|l|}{ Outcomes } \\
\hline ICU admission $\leq 3$ days, $\mathrm{n}(\%)$ & $201(4.4)$ & $102(5.2)$ & 0.15 \\
\hline 3-day mortality, n (\%) & $41(0.9)$ & $12(0.6)$ & 0.24 \\
\hline 28-day ICU admissions, n (\%) & $259(5.6)$ & $119(6.0)$ & 0.51 \\
\hline 28-day mortality, n (\%) & $184(4.0)$ & $78(4.0)$ & 0.94 \\
\hline
\end{tabular}

Missing values were assumed to be normal for arterial $\mathrm{pH}(\mathrm{n}=4247,65 \%)$, arterial partial pressure of oxygen or oxygen saturation $(n=1029$, $15 \%)$, BUN $(n=1685,26 \%)$, sodium $(n=1565,24 \%)$, glucose $(n=1637,25 \%)$, haematocrit $(n=1205,18 \%), W B C(n=1185,18 \%)$. BP $=$ blood pressure; BUN = blood urea nitrogen; ICU' = intensive care unit; IQR = interquartile range; WBC = white blood cell.

comorbid condition of 1 or higher, tachypnoea, tachycardia, leukopenia or leukocytosis, multilobar infiltrates or pleural effusion, hypoxaemia, acidosis, hyperuraemia and hyponatraemia. From this set of variables, we derived a prediction rule, REAICU score, that demonstrated a consistent discriminatory power for predicting ICU admission occurring within three days of ED presentation for patients with CAP not requiring immediate ICU transfer.

The British Thoracic Society advocates using a set of only four variables (CURB-65) and suggests considering ICU referral when three or more criteria are present [13]. The ATS rule, modified in 2001 [16], appears to have a slightly better predicting accuracy than the CURB-65 or the PSI; however, it still results in a substantial proportion of patients misclassified with regard to ICU admission [17]. Moreover, the two major criteria of the ATS rule - requirements for mechanical ventilation and the occurrence of shock - are obvious reasons for ICU admis- sion. Espana and colleagues derived the SCAP prediction rule that was shown to discriminate better than previous prediction rules between ED patients with and without CAP-related adverse medical outcomes, including 30-day mortality and ICU referral [12]. Narrowing the criteria for severe CAP needing ICU admission to the requirement for intensive respiratory or vasopressor support (IRVS), Charles and colleagues recently developed the SMART-COP, which demonstrated interesting characteristics to predict IRVS requirement during the whole hospital course of patients [18]. We took a different perspective and focused on patients not presenting to the ED with a need for IRVS, but subsequently transferred to the ICU within the first three days of admission; thus, our index might be especially useful for emergency physicians to assess the potential risk of ICU requirement within the next few days among those patients presenting with none of the ATS major severity criteria. As a result, the REA-ICU performed significantly better than existing prediction rules (PSI, CURB-65, 
Association of patient demographic characteristics, comorbid conditions and baseline physical examination findings with intensive care unit admission within three days of presentation

\begin{tabular}{|c|c|c|c|c|c|c|}
\hline \multirow[t]{3}{*}{ Characteristics } & \multirow{2}{*}{\multicolumn{2}{|c|}{$\begin{array}{c}\text { Derivation cohort } \\
\text { Admission to } \mathrm{ICU} \leq 3 \text { days }\end{array}$}} & \multicolumn{4}{|c|}{ Validation cohort } \\
\hline & & & \multirow[t]{2}{*}{$P$ value } & \multicolumn{2}{|c|}{ Admission to $\mathrm{ICU} \leq 3$ days } & \multirow[t]{2}{*}{$P$ value ${ }^{\star}$} \\
\hline & No (4392) & Yes (201) & & No (1865) & Yes (102) & \\
\hline \multicolumn{7}{|l|}{ Demographic factors } \\
\hline Male gender, $\%$ & 52.4 & 63.7 & 0.002 & 52.5 & 59.8 & 0.15 \\
\hline Age, mean (SD) years & $59(21)$ & $67(15)$ & $<0.001$ & $60(21)$ & $65(16)$ & 0.01 \\
\hline \multicolumn{7}{|l|}{ Comorbid conditions, $\%$} \\
\hline Cancer & 5.0 & 5.5 & 0.75 & 5.8 & 11.8 & 0.01 \\
\hline Cerebrovascular disease & 6.8 & 8.9 & 0.15 & 6.9 & 6.5 & 0.87 \\
\hline Liver disease & 1.5 & 20. & 0.60 & 1.4 & 3.9 & 0.04 \\
\hline Congestive heart failure & 11.2 & 25.9 & $<0.001$ & 11.4 & 21.6 & 0.002 \\
\hline Renal disease & 4.9 & 14.4 & $<0.001$ & 5.4 & 10.8 & 0.02 \\
\hline Coronary artery disease & 16.6 & 30.8 & $<0.001$ & 15.9 & 20.6 & 0.21 \\
\hline Chronic pulmonary disease & 24.8 & 31.3 & 0.04 & 23.9 & 28.4 & 0.29 \\
\hline Diabetes mellitus & 14.3 & 21.4 & 0.006 & 13.7 & 27.4 & $<0.001$ \\
\hline \multicolumn{7}{|l|}{ Physical examination findings, $\%$} \\
\hline Altered mental status & 5.5 & 15.9 & $<0.001$ & 5.7 & 12.7 & 0.004 \\
\hline Respiratory rate $\geq 30$ breaths/minute & 12.3 & 33.8 & $<0.001$ & 11.5 & 35.3 & $<0.001$ \\
\hline Systolic BP $<90 \mathrm{mmHg}$ & 1.5 & 5.0 & $<0.001$ & 1.2 & 2.0 & 0.48 \\
\hline Temperature $<35$ or $\geq 40^{\circ} \mathrm{C}$ & 5.6 & 9.4 & 0.02 & 5.8 & 12.7 & 0.005 \\
\hline Pulse $\geq 125$ beats/minute & 8.8 & 18.4 & $<0.001$ & 7.5 & 23.5 & $<0.001$ \\
\hline Oxygen saturation, $<90 \%$ & 13.6 & 44.4 & $<0.001$ & 14.0 & 46.4 & $<0.001$ \\
\hline
\end{tabular}

Admission to ICU $\leq 3$ days refers to patients who were admitted to an ICU within 3 days of presentation at the emergency department. * $P$ value refers to the variables associated with admission to ICU within 3 days of presentation.

$\mathrm{BP}=$ blood pressure; ICU = intensive care unit; SD = standard deviation.

Espana SCAP) in predicting ICU admission on days 1 to 3 of ED presentation in these patients.

Indeed, the criteria for inclusion in our analysis have several distinctive features from previous attempts at predicting CAP severity. First, contrasting with previous prediction rules, we focused on the more challenging subgroup of patients presenting with moderately severe CAP and no requirement for immediate ICU admission [11]; hence, we excluded patients with obvious respiratory or haemodynamic failure at presentation. Indeed, including such clinically apparent features in a prediction rule is likely to improve its operative characteristics, but is of limited value in assisting physicians in triaging patients $[19,20]$

Second, we focused on admission to ICU within three days of ED presentation, instead of including all 28-day outcomes. Pneumonia is the most common cause of severe sepsis, and severe CAP should be seized in the overall context of sepsis from pulmonary infection with organ dysfunction(s) potentially requiring intensive care $[5,21]$. Indeed, most sepsis-related organ failures in this setting occur early [3,22]. Accordingly, our findings in a large sample of patients presenting with CAP confirm that admission to ICU mostly occurred within the first three days of ED presentation. In addition, late ICU admissions may be associated with other factors than the severity of pneumonia itself (e.g. decompensated comorbidity or an intercurrent event), and not be influenced by its initial management [23-25]. Moreover, the REA-ICU score was based on data readily available at patient presentation to the ED and did not include results from ED monitoring, which would be less relevant to triaging patients in the ED setting $[12,26]$. Accordingly, we could not include laboratory tests that were not evenly collected across the four original studies (e.g. albuminaemia). 


\begin{tabular}{|c|c|c|c|c|c|c|}
\hline \multirow[t]{3}{*}{ Characteristics } & \multirow{2}{*}{\multicolumn{2}{|c|}{$\begin{array}{l}\text { Derivation cohort } \\
\text { Admission to ICU } \\
\leq 3 \text { days }\end{array}$}} & \multicolumn{4}{|c|}{ Validation cohort } \\
\hline & & & \multirow[t]{2}{*}{$P$ value } & \multicolumn{2}{|c|}{$\begin{array}{l}\text { Admission to } \\
\mathrm{ICU} \leq 3 \text { days }\end{array}$} & \multirow[t]{2}{*}{$P$ value } \\
\hline & No (4392) & Yes (201) & & No (1865) & Yes (102) & \\
\hline \multicolumn{7}{|c|}{ Laboratory and $\mathrm{x}$-ray findings, $\%$} \\
\hline Arterial $\mathrm{pH}<7.35$ & 2.3 & 10.9 & $<0.001$ & 2.6 & 19.6 & $<0.001$ \\
\hline $\mathrm{BUN} \geq 10 \mathrm{mmol} / \mathrm{L}$ & 13.0 & 37.8 & $<0.001$ & 12.9 & 30.4 & $<0.001$ \\
\hline Sodium $<130 \mathrm{mEq} / \mathrm{L}$ & 3.9 & 11.7 & $<0.001$ & 3.0 & 13.0 & $<0.001$ \\
\hline Glucose $\geq 14 \mathrm{mmol} / \mathrm{dL}$ & 4.8 & 9.9 & 0.001 & 5.1 & 10.9 & 0.02 \\
\hline Haematocrit $<30 \%$ & 4.5 & 10.9 & $<0.001$ & 4.7 & 11.8 & 0.002 \\
\hline $\mathrm{WBC}<3$ or $\geq 20 \mathrm{G} / \mathrm{L}$ & 9.1 & 18.9 & $<0.001$ & 8.4 & 18.6 & $<0.001$ \\
\hline $\mathrm{PaO}_{2}<60 \mathrm{mmHg}$ & 21.9 & 54.7 & $<0.001$ & 18.9 & 56.9 & $<0.001$ \\
\hline Pleural effusion & 10.4 & 21.9 & $<0.001$ & 10.1 & 17.6 & 0.01 \\
\hline Multilobar infiltrates & 22.0 & 41.8 & $<0.001$ & 22.2 & 39.2 & $<0.001$ \\
\hline \multicolumn{7}{|c|}{ Pneumonia Severity Index, \% } \\
\hline Class I & 28.4 & 5.0 & $<0.001$ & 28.6 & 4.9 & $<0.001$ \\
\hline Class II & 24.0 & 10.9 & & 24.9 & 13.7 & \\
\hline Class III & 19.1 & 17.9 & & 18.7 & 22.5 & \\
\hline Class IV & 23.0 & 46.8 & & 22.2 & 35.3 & \\
\hline Class V & 5.4 & 19.4 & & 5.5 & 23.5 & \\
\hline
\end{tabular}

Admission to ICU $\leq 3$ days refers to patients who were admitted to an ICU within three days of presentation to the emergency department. * $P$ value refers to the variables associated with admission to ICU within 3 days of presentation. BUN = blood urea nitrogen; ICU = intensive care unit; $\mathrm{PaO}_{2}=$ arterial partial pressure of oxygen; $\mathrm{WBC}=$ white blood cell.

Third, we considered that adequate ICU admission should not be restricted to patients requiring IRVS [19]. Indeed, ICU care has been demonstrated to improve outcome in severely ill and unstable patients, and these patients require intensive monitoring and may potentially need immediate intervention [27]. Therefore, given the characteristics of the REA-ICU (Additional data file 2), we suggest that intensive care physicians be informed of those patients with the highest risk of three-day ICU admission. This could be achieved by requesting the advice of an intensivist for such patients, who would then help decide on the most appropriate site of care for providing them adequate management and close monitoring, possibly in the ICU or an intermediate-care unit as deemed appropriate.

Fourth, despite substantial differences across the four original cohorts in patient characteristics and outcomes (Tables 1 and 2) [6-9], the overall discriminatory power of the REA-ICU score in predicting ICU admission on days 1 to 3 was quite high across the four original cohorts, reflecting the robustness of this score [28].

Several potential limitations of our study must be acknowledged. First, there were slight methodological differences and exclusion criteria across the four cohorts analysed. However, the definitions used in EDCAP, Pneumocom-1 and Pneumocom-2 were all based on the Pneumonia PORT study. Second, our findings do not take into account processes of care or causative pathogens, which may have confounded the relation between risk class and patient outcomes. As these data were not collected in a standardised manner across the four studies, we could not adjust for these variables. Third, the REA-ICU score includes 11 variables, which might limit its applicability to clinical use. However, the 20-variable PSI has been successfully implemented in various settings, including routine practice [7,9,29-31]. Fourth, our findings are based solely on hospital admission data and patient monitoring data were not recorded during the initial hospital course, so we 
Table 5

Adjusted coefficients and odd ratios for admission to ICU within three days of presentation and points assigned in the predictive model

\begin{tabular}{|c|c|c|c|c|c|}
\hline Characteristics & $\begin{array}{c}\beta \\
\text { parameter }\end{array}$ & 95\% $\mathrm{Cl}$ ( $\beta$ parameter) & OR & $95 \% \mathrm{Cl}(\mathrm{OR})$ & $\begin{array}{c}\text { Points } \\
\text { assigned }\end{array}$ \\
\hline Male & 0.39 & $(0.08$ to 0.70$)$ & 1.47 & (1.08 to 2.01$)$ & 1 \\
\hline Comorbid condition $\geq 1$ & 0.45 & $(0.11$ to 0.78$)$ & 1.57 & (1.12 to 2.19$)$ & 1 \\
\hline Respiratory rate $\geq 30$ breaths/minutes & 0.53 & $(0.18$ to 0.88$)$ & 1.70 & (1.20 to 2.41$)$ & 1 \\
\hline White blood cell count $<3$ or $\geq 20 \mathrm{G} / \mathrm{L}$ & 0.54 & $(0.14$ to 0.94$)$ & 1.71 & (1.15 to 2.55$)$ & 1 \\
\hline Heart rate $\geq 125$ beats/minute & 0.55 & (0.14 to 0.95$)$ & 1.73 & (1.15 to 2.60$)$ & 1 \\
\hline Age $<80$ years & 0.57 & $(0.18$ to 0.95$)$ & 1.76 & (1.19 to 2.59$)$ & 1 \\
\hline Multilobar infiltrates or pleural effusion & 0.79 & (0.48 to 1.09$)$ & 2.19 & (1.62 to 2.97$)$ & 2 \\
\hline Oxygen saturation $<90 \%$ or $\mathrm{PaO}_{2}<60 \mathrm{mmHg}$ & 0.85 & (0.53 to 1.17$)$ & 2.35 & (1.71 to 3.23$)$ & 2 \\
\hline Arterial $\mathrm{pH}<7.35$ & 0.91 & $(0.38$ to 1.44$)$ & 2.49 & (1.47 to 4.22$)$ & 2 \\
\hline Blood urea nitrogen $\geq 11 \mathrm{mmol} / \mathrm{L}$ & 0.94 & $(0.61$ to 1.28$)$ & 2.56 & (1.84 to 3.58$)$ & 2 \\
\hline Sodium $<130 \mathrm{mEq} / \mathrm{L}$ & 1.06 & (0.58 to 1.53$)$ & 2.88 & (1.79 to 4.63$)$ & 3 \\
\hline
\end{tabular}

$\mathrm{Cl}=$ confidence Interval; $\mathrm{OR}=$ odds ratio $\mathrm{PaO}_{2}=$ arterial partial pressure of oxygen.

could not analyse the adequacy of secondary ICU admission (e.g. requirement for mechanical ventilation or vasopressor, or other reason for ICU admission). Fifth, all laboratory tests were performed at the discretion of the attending physicians and missing values were assumed to be normal. This strategy is widely used in the clinical application of prediction rules and reflects the methods used in the original derivation and validation of the PSI [15]. Indeed, patients with less severe illness were more likely to have missing values for laboratory findings. Finally, prediction scores often perform better in their deriva- tion and internal validation cohorts than in external validation studies; therefore, external independent validation is required.

\section{Conclusions}

In summary, using a large database combining four prospective cohorts of patients with CAP, we derived and validated the REA-ICU index to predict ICU referral within the first three days of hospital admission in patients without overt circulatory or respiratory failure at ED presentation. This index demonstrates valuable characteristics for stratifying the risk of admission to ICU on hospital days 1 to 3 . Using this combination of

Table 6

Population and outcomes stratification according to the risk of early ICU admission index (REA-ICU index) of patients with community acquired pneumonia

\begin{tabular}{|c|c|c|c|c|c|c|c|}
\hline \multirow[b]{2}{*}{ Risk class } & \multirow[b]{2}{*}{ Score } & \multicolumn{3}{|c|}{ Derivation population } & \multicolumn{3}{|c|}{ Validation population } \\
\hline & & $\mathrm{N}$ & $\begin{array}{c}\mathrm{ICU} \leq 3 \text { days, } \\
\%(95 \% \mathrm{Cl})\end{array}$ & $\begin{array}{c}\text { Death } \leq 28 \text { days, } \\
\%(95 \% \mathrm{Cl})\end{array}$ & $\mathrm{n}$ & $\begin{array}{c}\mathrm{ICU} \leq 3 \text { days, } \\
\%(95 \% \mathrm{CI})\end{array}$ & $\begin{array}{c}\text { Death } \leq 28 \text { days } \\
\%(95 \% \mathrm{Cl})\end{array}$ \\
\hline I & $\leq 3$ & 2510 & $\begin{array}{c}1.1 \\
(0.7 \text { to } 1.6)\end{array}$ & $\begin{array}{c}1.2 \\
(0.8 \text { to } 1.8)\end{array}$ & 1099 & $\begin{array}{c}1.3 \\
(0.7 \text { to } 2.1)\end{array}$ & $\begin{array}{c}1.9 \\
(1.2 \text { to } 2.9)\end{array}$ \\
\hline II & 4 to 6 & 1498 & $\begin{array}{c}5.5 \\
(4.4 \text { to } 6.8)\end{array}$ & $\begin{array}{c}6.0 \\
(4.8 \text { to } 7.3)\end{array}$ & 633 & $\begin{array}{c}7.1 \\
\text { (5.2 to } 9.4 \text { ) }\end{array}$ & $\begin{array}{c}4.4 \\
\text { (3.0 to } 6.3 \text { ) }\end{array}$ \\
\hline III & 7 to 8 & 419 & $\begin{array}{c}11.0 \\
(8.2 \text { to } 14.4)\end{array}$ & $\begin{array}{c}9.1 \\
\text { (6.5 to } 12.2)\end{array}$ & 164 & $\begin{array}{c}12.2 \\
(7.6 \text { to } 18.2)\end{array}$ & $\begin{array}{c}7.9 \\
(4.2 \text { to } 13.2)\end{array}$ \\
\hline IV & $\geq 9$ & 166 & $\begin{array}{c}27.1 \\
(20.5 \text { to } 34.5)\end{array}$ & $\begin{array}{c}15.1 \\
(10.0 \text { to } 21.4)\end{array}$ & 71 & $\begin{array}{c}32.4 \\
(21.7 \text { to } 44.5)\end{array}$ & $\begin{array}{c}22.5 \\
(13.5 \text { to } 34.0)\end{array}$ \\
\hline Total & & 4593 & $\begin{array}{c}4.4 \\
\text { (6.0 to } 7.4)\end{array}$ & $\begin{array}{c}4.0 \\
(3.4 \text { to } 4.6)\end{array}$ & 1967 & $\begin{array}{c}5.2 \\
(5.8 \text { to } 8.0)\end{array}$ & $\begin{array}{c}4.0 \\
\text { (3.1 to } 4.9)\end{array}$ \\
\hline
\end{tabular}

$\mathrm{ICU} \leq 3$ days and death $\leq 28$ days refer to patients who were admitted to an ICU within three days of presentation to the emergency department or who died within 28 days of presentation, respectively. Results are expressed as percentages of each outcome within each REA-ICU risk class. $\mathrm{Cl}=$ confidence interval; ICU $=$ intensive care unit. 
variables might help ED physicians to more accurately assess the potential need for ICU admission in the challenging group of high-risk patients presenting with no obvious reason for ICU admission $[5,32,33]$.

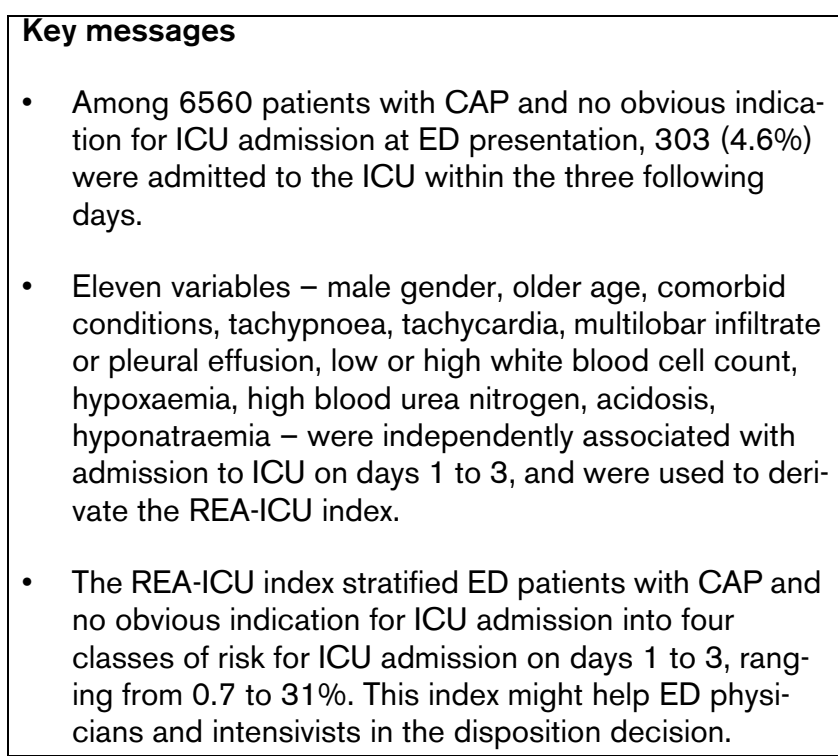

\section{Competing interests}

MJF consults for the University of Pennsylvania and GeneSoft Pharmaceuticals Inc. He also receiveds honoraria from Zynx Health Corporation, STA Healthcare Communications Inc., University of Alberta and Maine Medical Center). MJF gives expert testimony for Stephen Lynn Klein, Kellogg \& Siegelman, Swanson, Martin, \& Bell, William J. Burke, Chad McGowan, Chernett, Wasserman, Yarger and Pasternak, LLC. MJF received grants from Pfizer Inc. BR received grants from GlaxoSmithKline Inc. MJF also received royalties from Up-to-Date.

\section{Authors' contributions}

$\mathrm{BR}, \mathrm{JL}, \mathrm{CBB}$ made substantial contributions to conception and design. BR, JL, EC, AS, MG, NC, ER, FH, JH, MS, MJF and $\mathrm{CBB}$ made substantial contributions to acquisition of data. BR, JL, EC, AS, NC, MS, MJF and CBB made substantial contributions to analysis and interpretation of data. BR, JL, EC, AS, MG, MJF, FH, JH and CBB were involved in drafting the manuscript or revising it critically for important intellectual content. BR, JL, EC, AS, MG, NC, ER, FH, JH, MS, MJF and CBB gave their final approval of the version to be published. BR, EC, AS, MG, ER, JH, MS and MJF were involved in acquisition of funding and collection of data. BR, EC, AS, MG, MJF and CBB were involved in general supervision of the research group.

\section{Additional files}

The following Additional files are available online:

\section{Additional file 1}

Word file containing a table comparing study patient exclusion criteria across the four original study

populations.

See http://www.biomedcentral.com/content/ supplementary/cc7781-S1.doc

\section{Additional file 2}

Word file containing a table that describes the risk of early intensive care unit admission index characteristics. See http://www.biomedcentral.com/content/ supplementary/cc7781-S2.doc

\section{Acknowledgements}

This study was funded by the "Direction de la Recherche Clinique d'lle de France" as part of the "Programme Hospitalier de Recherche Clinique" (Grant NAOM 89-145).

BR was supported by the "Département de la Formation Continue des Médecins de l'Assistance Publique des Hôpitaux de Paris (AP-HP)", by I'ARMUR (Association de Recherche en Médecine d'Urgence, Henri Mondor, Créteil) France, by AQUARE (Association pour la QUAlité, la Recherche et l'Enseignement à l'Hôpital Saint-Joseph (Paris)), and by GlaxoSmithKline France.

$\mathrm{JL}$ was supported by a grant from the Egide Foundation (French Foreign Office, Programme Lavoisier) and by Grenoble university hospital (Direction de la Recherche Clinique).

Participants in the Pneumocom study group made substantial contributions to acquisition of data. Dr Laurent Delaire and Dr Sylvie Betoulle (Centre Hospitalier Général d'Angoulême), Dr Philippe Grippon (Centre Hospitalier Général de Fontainebleau), Dr Jean François Cibien, Dr Cécile Noyez and Dr Pierre Mardegan (Centre Hospitalier Général de Montauban), Dr Alain Cannamela, Dr Thomas Guérin and Dr Emmanuelle Fritsch (Centre Hospitalier Général de Roanne), Dr JeanPierre Bal and Dr Marie-Pierre Bertrand (Centre Hospitalier Inter-Communal de Créteil), Dr Nicolas Simon and Luce Guérin (Centre Hospitalier Inter-Communal de Poissy-Saint-Germain-en-Laye), Dr Jérôme Khazakha and Dr Lafontaine (Centre Hospitalier Inter-Communal de Tarbes), Dr Didier Jan and Dr Emmanuel Carre (Centre Hospitalier Régional de Vannes), Dr Isabelle Claude, Dr Moulin and Dr Gilles Mehu (Centre Hospitalier de Quimper, Quimper, France), Dr Alain Delhumeau, Dr Pierre Marie Roy and Dr Betty Mazet (Centre Hospitalier Universitaire d'Angers), Dr Dominique Pateron and Dr Joelle Benkel (Centre Hospitalier Universitaire de Bondy), Dr Françoise Carpentier, Dr Marc Blancher and Dr Caroline Douchant (Centre Hospitalier Universitaire de Grenoble), Dr Gilles Potel, Dr Philippe Leconte and Dr Celine Longo (Centre Hospitalier Universitaire de Nantes), Dr Jean Rouffineau and Dr Hélène Boureaux (Centre Hospitalier Universitaire de Poitiers), Dr Jacques Bouget, Dr Isabelle Jouannic and Dr Marie-Hélène Marquez 
(Centre Hospitalier Universitaire de Rennes), Dr Muller, Dr Fabienne Moritz, Dr Joël Jenvrin and Dr lliasse Idrissi (Centre Hospitalier Universitaire de Rouen), Dr Hervé Jérôme, Dr Alfred Ngako, Dr Marie-Jeanne Calmette, Dr Virginie Lemiale, Dr Marie Debacker and Dr Cyril Boraud (Centre Hospitalier Universitaire Henri Mondor, Créteil), Dr Guillermo Vazquez-Mata (Hospital de Sant Pau, Barcelona), Dr Joseph Gomez and Josep Solis (Hospital Nostra Senyora de Meritxell, Andorra), Dr Sara Graell, Sngels Lamarca and Antonia Lopez (Hospital de Terrassa), Dr Josep Alba and Francesc Chavales (Hospital de l'Alt Penedes, Vilafranca), Dr Mireia Ferrer and Montserrat Costa (Hospital Municipal de Badalona), Dr Carme Agusti and Santi Tomas (Hospital Mutua de Terrassa), Dr Antoni Ayuso and Esther Costa (Clinica Platon, Barcelona), Dr Carles Ferré and Imma Sanchez (Funadació Sanitària d'Igualada), Dr Hisao Onaga and Angel Garcia (Hospital Josep Trueta, Girona), Dr Marina Gomez and Anna Coll (Hospital d'Olot), Dr Joseph Lluis Tricas and Francesc Xavier Altimiras (Hospital de Mollet), Dr Sonia Vega and Carles Sardà (Hospital de Figueres), Dr Oscar Len (Hospital Vall D'Hebró, Barcelona), Dr Gemma Vidal and Josep Font (Consorci Sanitari del Parc Taulí, Sabadell).

\section{References}

1. Valles J: Severe pneumonia: sources of infection and implications for prevention. Sepsis 1998, 1:199-209.

2. Woodhead MA, Macfarlane JT, Rodgers FG, Laverick A, Pilkington $\mathrm{R}$, Macrae AD: Aetiology and outcome of severe communityacquired pneumonia. J Infect 1985, 10:204-210.

3. Dremsizov T, Clermont G, Kellum JA, Kalassian KG, Fine MJ, Angus DC: Severe sepsis in community-acquired pneumonia: when does it happen, and do systemic inflammatory response syndrome criteria help predict course? Chest 2006, 129:968-978.

4. Leroy O, Santre C, Beuscart C, Georges H, Guery B, Jacquier JM, Beaucaire G: A five-year study of severe community-acquired pneumonia with emphasis on prognosis in patients admitted to an intensive care unit. Intensive Care Med 1995, 21:24-31.

5. Huang DT, Yealy DM: Decision rules and pneumonia: What are we "predicting", and for whom? Am J Respir Crit Care Med 2006, 174:1169-1170.

6. Fine MJ, Auble TE, Yealy DM, Hanusa BH, Weissfeld LA, Singer DE, Coley CM, Marrie TJ, Kapoor WN: A prediction rule to identify low-risk patients with community-acquired pneumonia. $N$ Engl J Med 1997, 336:243-250.

7. Renaud B, Coma E, Labarere J, Hayon J, Roy PM, Boureaux $\mathrm{H}$, Moritz F, Cibien JF, Guerin T, Carre E, Lafontaine A, Bertrand MP, Santin A, Brun-Buisson C, Fine MJ, Roupie E, Pneumocom Study Investigators: Routine use of the Pneumonia Severity Index for guiding the site-of-treatment decision of patients with pneumonia in the emergency department: a multicenter, prospective, observational, controlled cohort study. Clin Infect Dis 2007, 44:41-49.

8. Renaud B, Coma E, Hayon J, Gurgui M, Longo C, Blancher M, Jouannic I, Betoulle S, Roupie E, Fine MJ: Investigation of the ability of the Pneumonia Severity Index to accurately predict clinically relevant outcomes: a European study. Clin Microbiol Infect 2007, 13:923-931.

9. Yealy DM, Auble TE, Stone RA, Lave JR, Meehan TP, Graff LG, Fine JM, Obrosky DS, Mor MK, Whittle J, Fine MJ: Effect of increasing the intensity of implementing pneumonia guidelines: a randomized, controlled trial. Ann Intern Med 2005, 143:881-894.

10. Guidelines for the management of adults with hospitalacquired, ventilator-associated, and healthcare-associated pneumonia. Am J Respir Crit Care Med 2005, 171:388-416.

11. Mandell LA, Wunderink RG, Anzueto A, Bartlett JG, Campbell GD, Dean NC, Dowell SF, File TM Jr, Musher DM, Niederman MS, Torres A, Whitney CG, Infectious Diseases Society of America, American Thoracic Society: Infectious diseases society of america/american thoracic society consensus guidelines on the management of community-acquired pneumonia in adults. Clin Infect Dis 2007, 44(Suppl 2):S27-72.
12. Espana PP, Capelastegui A, Gorordo I, Esteban C, Oribe M, Ortega M, Bilbao A, Quintana JM: Development and validation of a clinical prediction rule for severe community-acquired pneumonia. Am J Respir Crit Care Med 2006, 174:1249-1256.

13. Lim WS, Eerden MM van der, Laing R, Boersma WG, Karalus N, Town Gl, Lewis SA, Macfarlane JT: Defining community acquired pneumonia severity on presentation to hospital: an international derivation and validation study. Thorax 2003, 58:377-382.

14. Sirio CA, Shepardson LB, Rotondi AJ, Cooper GS, Angus DC Harper DL, Rosenthal GE: Community-wide assessment of intensive care outcomes using a physiologically based prognostic measure: implications for critical care delivery from Cleveland Health Quality Choice. Chest 1999, 115:793-801.

15. Aujesky D, Auble TE, Yealy DM, Stone RA, Obrosky DS, Meehan TP, Graff LG, Fine JM, Fine MJ: Prospective comparison of three validated prediction rules for prognosis in communityacquired pneumonia. Am J Med 2005, 118:384-392.

16. Niederman MS, Mandell LA, Anzueto A, Bass JB, Broughton WA, Campbell GD, Dean N, File T, Fine MJ, Gross PA, Martinez F, Marrie TJ, Plouffe JF, Ramirez J, Sarosi GA, Torres A, Wilson R, Yu VL, American Thoracic Society: Guidelines for the management of adults with community-acquired pneumonia. Diagnosis, assessment of severity, antimicrobial therapy, and prevention. Am J Respir Crit Care Med 2001, 163:1730-1754.

17. Angus DC, Marrie TJ, Obrosky DS, Clermont G, Dremsizov TT, Coley C, Fine MJ, Singer DE, Kapoor WN: Severe communityacquired pneumonia: use of intensive care services and evaluation of American and British Thoracic Society Diagnostic criteria. Am J Respir Crit Care Med 2002, 166:717-723.

18. Charles PG, Wolfe R, Whitby M, Fine MJ, Fuller AJ, Stirling $R$, Wright AA, Ramirez JA, Christiansen KJ, Waterer GW, Pierce RJ, Armstrong JG, Korman TM, Holmes P, Obrosky DS, Peyrani P, Johnson B, Hooy M, Australian Community-Acquired Pneumonia Study Collaboration, Grayson ML: SMART-COP: a tool for predicting the need for intensive respiratory or vasopressor support in community-acquired pneumonia. Clin Infect Dis 2008, 47(3):375-384

19. Ewig S: Against misleading predictions for severe communityacquired pneumonia. Am J Respir Crit Care Med 2007, 175:289. Author reply $289-290$.

20. Sox HC: Medical decision making. Boston: Butterworths; 1988.

21. Wang HE, Shapiro NI, Angus DC, Yealy DM: National estimates of severe sepsis in United States emergency departments. Crit Care Med 2007, 35:1928-1936.

22. Brun-Buisson $C$, Doyon F, Carlet J, Dellamonica $P$, Gouin F, Lepoutre A, Mercier JC, Offenstadt G, Regnier B: Incidence, risk factors, and outcome of severe sepsis and septic shock in adults. A multicenter prospective study in intensive care units. French ICU Group for Severe Sepsis. JAMA 1995, 274:968-974.

23. Dellinger RP, Carlet JM, Masur $\mathrm{H}$, Gerlach H, Calandra T, Cohen J, Gea-Banacloche J, Keh D, Marshall JC, Parker MM, Ramsay G, Zimmerman JL, Vincent JL, Levy MM, Surviving Sepsis Campaign Management Guidelines Committee: Surviving Sepsis Campaign guidelines for management of severe sepsis and septic shock. Intensive Care Med 2004, 30:536-555.

24. Osborn TM, Nguyen HB, Rivers EP: Emergency medicine and the surviving sepsis campaign: an international approach to managing severe sepsis and septic shock. Ann Emerg Med 2005, 46:228-231.

25. Shapiro NI, Howell MD, Talmor D, Lahey D, Ngo L, Buras J, Wolfe $\mathrm{RE}$, Weiss JW, Lisbon A: Implementation and outcomes of the Multiple Urgent Sepsis Therapies (MUST) protocol. Crit Care Med 2006, 34:1025-1032.

26. Ewig S, Ruiz M, Mensa J, Marcos MA, Martinez JA, Arancibia F Niederman MS, Torres A: Severe community-acquired pneumonia. Assessment of severity criteria. Am J Respir Crit Care Med 1998, 158:1102-1108.

27. Guidelines for intensive care unit admission, discharge, and triage. Task Force of the American College of Critical Care Medicine, Society of Critical Care Medicine. Crit Care Med 1999, 27:633-638.

28. Justice AC, Covinsky KE, Berlin JA: Assessing the generalizability of prognostic information. Ann Intern Med 1999, 130:515-524.

29. Marrie TJ, Lau CY, Wheeler SL, Wong CJ, Vandervoort MK, Feagan BG: A controlled trial of a critical pathway for treatment of 
community-acquired pneumonia. CAPITAL Study Investigators. Community-Acquired Pneumonia Intervention Trial Assessing Levofloxacin. JAMA 2000, 283:749-755.

30. Atlas SJ, Benzer TI, Borowsky LH, Chang Y, Burnham DC, Metlay JP, Halm EA, Singer DE: Safely increasing the proportion of patients with community-acquired pneumonia treated as outpatients: an interventional trial. Arch Intern Med 1998, 158:1350-1356.

31. Carratala J, Fernandez-Sabe N, Ortega L, Castellsague X, Roson B, Dorca J, Fernandez-Aguera A, Verdaguer R, Martinez J, Manresa F, Gudiol F: Outpatient care compared with hospitalization for community-acquired pneumonia: a randomized trial in lowrisk patients. Ann Intern Med 2005, 142:165-172.

32. McGinn TG, Guyatt GH, Wyer PC, Naylor CD, Stiell IG, Richardson WS: Users' guides to the medical literature: XXII: how to use articles about clinical decision rules. Evidence-Based Medicine Working Group. JAMA 2000, 284:79-84.

33. Alberti C, Brun-Buisson C, Chevret S, Antonelli M, Goodman SV, Martin C, Moreno R, Ochagavia AR, Palazzo M, Werdan K, Le Gall $J R$, European Sepsis Study Group: Systemic inflammatory response and progression to severe sepsis in critically ill infected patients. Am J Respir Crit Care Med 2005, 171:461-468. 